\title{
Algoritme Particle Swarm Optimization (PSO) untuk Optimasi Perencanaan Produksi Agregat Multi-Site pada Industri Tekstil Rumahan
}

\author{
Agung Mustika Rizki ${ }^{*}$, Afina Lina Nurlaili ${ }^{2}$ \\ 1 Informatika, UPN Veteran Jawa Timur; agung.mustika.if@upnjatim.ac.id \\ 2 Informatika, UPN Veteran Jawa Timur; afina.lina.if@upnjatim.ac.id \\ * Correspondence: agung.mustika.if@upnjatim.ac.id
}

\begin{abstract}
Abstrak: Dalam dunia industri, perusahaan perlu mengelola area produksinya dengan baik. Salah satu caranya adalah dengan menerapkan perencanaan produksi agregat. Hal ini bertujuan agar biaya produksi yang dikeluarkan perusahaan dapat terkontrol dengan baik. Namun, perencanaan produksi tidak dapat dirumuskan dengan cepat. Problem tersebut akan bertambah jika perusahaan memiliki beberapa lokasi produksi. Perbedaan lokasi juga mempengaruhi acuan produksi dan standar yang diterapkan di setiap lokasi. Berdasarkan permasalahan tersebut, penulis mengusulkan untuk menerapkan algoritma Particle Swarm Optimization (PSO) untuk menyelesaikan masalah perencanaan produksi agregat sehingga didapatkan solusi yang optimal untuk setiap lokasi produksi. Hasilnya, algoritma yang diajukan penulis dapat menghasilkan solusi yang optimal dan efisien untuk 6 lokasi produksi. Hal ini dibuktikan dengan waktu yang dibutuhkan relatif lebih singkat dibandingkan dengan perencanaan sebelumnya yang dilakukan oleh perusahaan.
\end{abstract}

Kata Kunci: Agregate Production Planning; Particle Swarm Optimization; Multi-site Industry

\section{Pendahuluan}

Indonesia merupakan negara dengan ekonomi yang berkembang pesat di kawasan Asia Tenggara. Hal ini tidak lepas dari banyaknya perusahan/industri melihat pasar di Indonesia cukup menjanjikan. Disamping itu pemerintah juga berperan aktif dalam mendukung pergerakan industri dalam negeri. Salah satu industri yang terus berkembang saat ini adaah industri tekstil. Hal ini disebabkan karena industri tekstil merupakan bagian pokok dari kebutuhan hidup manusia. Namun di bidang industri terdapat beberapa kendala rumit. Salah satu dari permasalahan tersebut adalah pelaku industri harus merencanakan proses produksi dengan tepat untuk menghadapi permintaan pasar yang sering berubah-ubah. Fluktuasi permintaan ini terjadi karena beberapa faktor diantaranya daya beli masyarakat, perkembangan ekonomi dan munculnya pelaku industri baru pada bidang tekstil. Dengan demikian pelaksanaan produksi harus dilakukan dengan efisien agar tidak berlebihan atau kekurangan. Untuk itu dibutuhkan perencanaan produksi agar permintaan konsumen terpenuhi dengan baik. Dalam hal ini perencanaan produksi agregat dapat dilakukan untuk menghasilkan proses produksi yang efisien tersebut. 


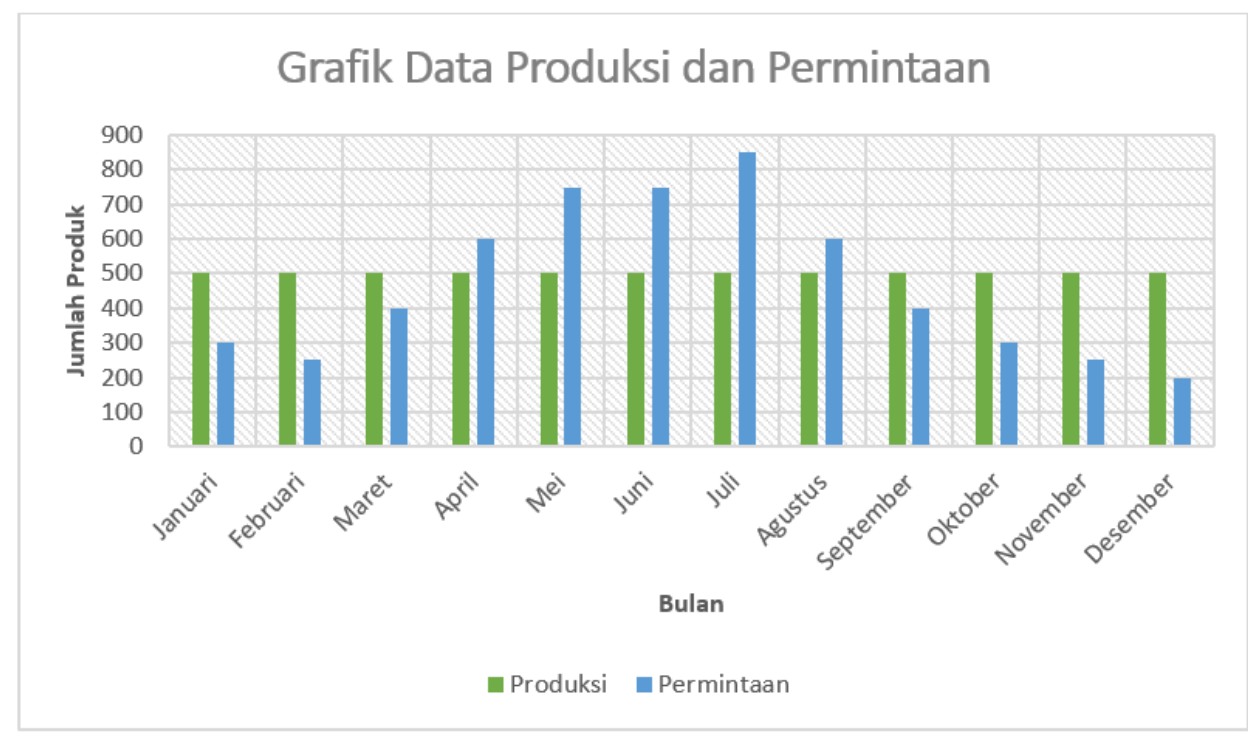

Gambar 1 Data Produksi Stabil

Berdasarkan data yang diperoleh dari tempat penelitian, ada 2 skema produksi yang diterapkan. Pada Gambar 1 dapat dilihat pelaksanaan proses produksi stabil tanpa mempertimbangkan permintaan pasar. Strategi ini memaksimalkan produksi selama satu tahun dengan menitikberatkan pada proses penyimpanan. Namun dalam strategi ini biaya penyimpanan harus dipertimbangkan karena dapat menyebabkan pembengkakakn biaya sehingga perusahaan tidak dapat memperoleh keuntungan yang maksimal. Disamping itu daya tahan suatu produk dalam penyimpanan juga harus diperhatikan.

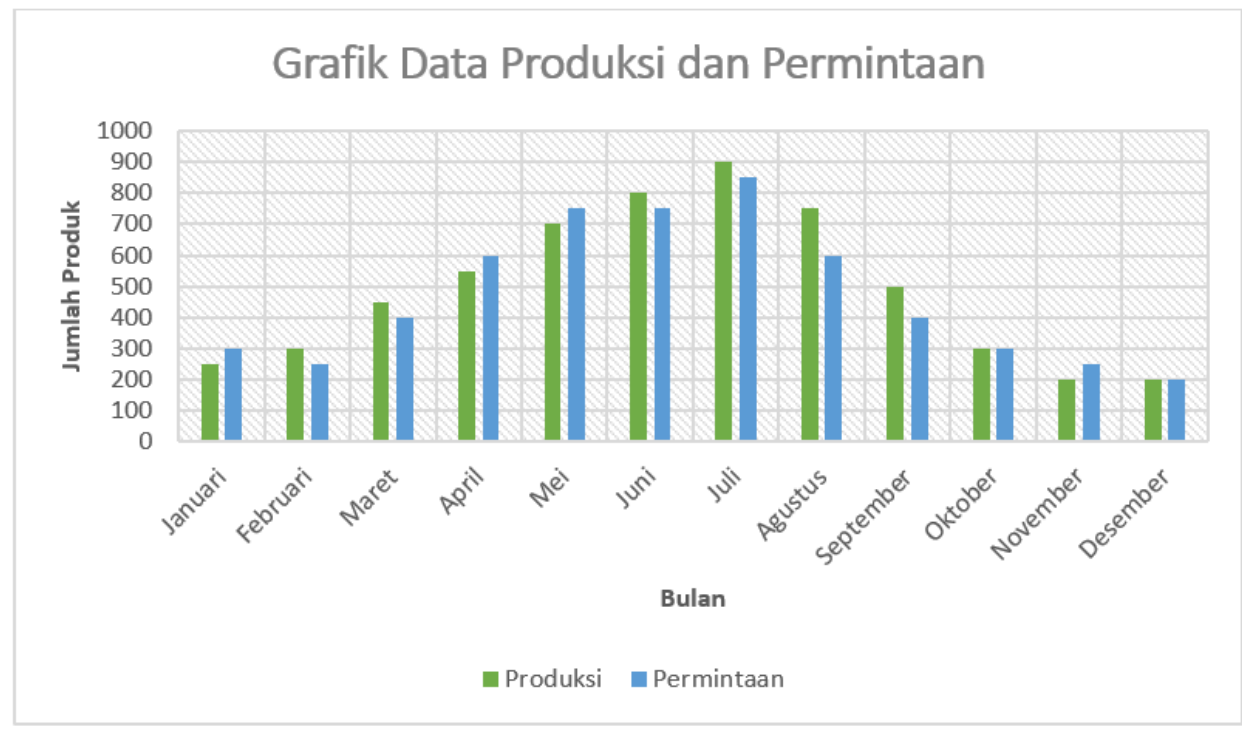

Gambar 2 Data Produksi Sesuai Permintaan

Strategi produksi lain dijelaskan pada Gambar 2, strategi ini lebih mempertimbangkan permintaan pasar sebagai acuan dalam melaksanakan proses produksi. Pada prakteknya strategi ini memilika beberapa kendala diantaranya pemaksimalan pegawai dan waktu kerja. Ketika permintaan melonjak ataupun turun maka perusahaan harus melakukan efisiensi pekerja dan waktu kerja dengan penambahan pegawai, pengurangan pegawai ataupun penambahan waktu lembur. Hal tersebut tentu saja dapat merugikan perusahaan dalam hal jika tidak ada kebijakan yang tepat.

Dari beberapa strategi tersebut, setiap perusahaan memiliki kebijakannya sendiri. Dalam hal ini industri tekstil rumahan sebagai objek penelitian memiliki permasalahn dalam proses produksinya. Industri ini memiliki beberapa tempat produksi yang tersebar di area Jawa Timur. Dengan lokasi 
yang berbeda tentu saja strategi produksi yang digunakan akan semakin rumit karena harus mempertimbangkan biaya dibeberapa daerah tersubut. Untuk perencanaan produksi agregat multisite diperlukan untuk menyelesaikan permasalahan tersebut.

Perencanaan produksi agregat adalah perencanaan yang bertujuan untuk menentukan jumlah produksi, persediaan, karyawan, tingkat lembur, dan tingkat kepuasan permintaan yang berujung pada biaya minimum atau keuntungan maksimal [1]. Pada tahap awal perencanaan produksi agregat adalah memperkirakan permintaan konsumen sebagai masukan dari proses perencanaan. Selanjutnya diperhitungkan juga ketersediaan bahan, pekerja, waktu produksi dan biaya yang dibutuhkan. Seperti masalah kombinatorial pada umumnya penyelesaian permasalahan ini cukup rumit. Disamping itu penyelesaian dengan cara biasa membutuhkan tenaga, pikiran dan waktu yang tidak sebentar untuk mendapatkan hasil yang paling optimal. Saat ini pelaku industri cenderung menggunakan perencanaan produksi dengan metode sederhana seperti Linier Programming dan Goal Programming [2]. Metode tersebut dianggap cukup efektif namun terkadang kesalahan kecil karena faktor manusia dapat menyebabkan kerugian bagi pihak perusahaan. Untuk itu dibutuhkan sebuah sistem yang dapat merencanakan agregat produksi sehingga dapat dicapai keuntungan optimal.

Sebelumnya terdapat penelitian perencanaan produksi agregat pada perusahaan penghasil tembakau rajang yang memiliki permintaan berfluktuasi. Beberapa strategi yang dipakai diantaranya Chase Strategy, Level Strategy dan Hybrid Strategy yang kemudian menghasilkan strategi agregat terpilih adalah Hybrid Strategy. Strategi ini menunjukkan total biaya produksi paling minimum sebesar Rp 34.309.781.219, dimana biaya produksi mengalami penghematan sebesar Rp 234.376.086 dari biaya produksi awal perusahaan [3]. Beberapa algoritme meta-heuristis dapat dijadikan solusi untuk menyelesaikan masalah ini. Salah satunya adalah algoritme Particle Swarm Optimization.

Particle Swarm Optimization adalah algoritme berbasis populasi yang memiliki sejumlah $n$ particle. Setiap hipotesis solusi dari permasalahan akan diwakili oleh partikel-partikel tersebut. Masing-masing partikel mengubah posisi terhadap waktu. Pada sistem PSO, partikel terbang mengitar ruang pencarian multi dimensional dan menyesuaikan posisinya berdasarkan pengalaman pribadinya dan pengalaman partikel kelompok [4]. Selanjutnya terdapat penelitian lain yang dilakukan oleh Mahmudy dkk. membahas penyelesaian permasalahan pada Flexible Manufacturing System (FMS). Yang pertama menggunakan Improved Particle Swarm Optimization. Dari penelitian tersebut membuktikan bahwa algoritme yang dipakai efektif untuk menyelesaikan permasalahan kombinatorial [5].

Berdasarkan pemaparan yang telah dibahas sebelumnya, disimpulkan bahwa dengan memanfaatkan metode Particle Swarm Optimization (PSO) dapat menyelesaikan permasalahan sejenis yang terstruktur. Oleh karena itu, dengan keadaan dan permasalahan yang ada seperti pada studi kasus mendorong penulis untuk membuat sebuah gagasan yakni merancang suatu sistem guna mendapatkan solusi yang optimal. Solusi dapat dikatakan optimal ketika biaya produksi dapat mencapai nilai seminimal mungkin. Hal tersebut menjadi latar belakang penulis untuk menyajikan studi kasus ini dengan menerapkan algoritme Particle Swarm Optimization (PSO) pada permasalahan perencanaan produksi agregat guna mengoptimalkan jumlah produksi pada industri tekstil rumahan. Studi kasus ini diharapkan mampu memberikan dampak yang positif pada bidang industri sehingga mampu menghasilkan perencanaan produksi agregat yang optimal dan sesuai dengan kebutuhan industri saat ini.

\section{Metodologi}

Particle Swarm Optimization (PSO) merupakan metode yang terinspirasi dari sifat alami sekelompok binatang seperti burung, rayap, lebah atau semut. Algoritme PSO mencontoh sifat alami beberapa organisme tersebut. Sifat ini terdiri dari kebiasaan yang dilakukan dalam kegiatan seharihari dan juga pengaruh individu satu terhadap individu-individu lainnya dalam suatu populasi. Kata "partikel" merujuk pada individu, contohnya seekor burung dalam populasi burung. Setiap 
individu atau partikel tersebut saling terhubung dengan kecerdasannya (intelligence) masing-masing dan juga dipengaruhi oleh perilaku kelompok lain dalam populasinya. Dengan adanya kondisi tersebut, jika salah satu partikel mendapatkan jalur yang efektif atau lebih pendek menuju ke sumber makanan, maka partikel lainnya juga akan mengikutin jalur tersebut meskipun lokasi awal mereka jauh dari kelompok tersebut [6].

Metode untuk optimasi berbasis kecerdasan partikel ini juga disebut sebagai algoritme behaviorally inspired yang dapat menjadi salah satu alternatif selain algoritme genetika, yang memang populer dengan evolution-based procedures. Untuk pertama kali algoritme PSO ini diusung oleh J. Kennedy dan R. C. Eberhart pada tahun 1995. Terkait dengan optimasi multi-variable, kelompok tersebut dapat diartikan memiliki ukuran tertentu atau tetap dimana setiap partikel posisi awalnya terdapat pada suatu lokasi secara acak dalam ruang multi dimensi. Setiap partikel memiliki dua karakteristik yakni posisi dan kecepatan.

Pada PSO terdapat tiga komponen penting antara lain: partikel, komponen kognitif dan komponen sosial, serta kecepatan partikel. Pada setiap partikel tersebut mewakili solusi dari suatu permasalahan yang dihadapi. Pembelajaran untuk partikel terdiri dari dua faktor yakni pengalaman partikel (cognitive learning) dan kombinasi pembelajaran dari keseluruhan swarm (social learning). Cognitive learning sebagai pBest yaitu posisi terbaik yang pernah dicapai suatu partikel, sedangkan social learning sebagai gBest yaitu posisi terbaik dari keseluruhan partikel dalam swarm. Parameter pBest dan gBest berfungsi untuk menghitung kecepatan partikel dan juga kecepatan untuk menghitung posisi partikel selanjutnya [6].

Terdapat beberapa factor penyusun pada algoritme PSO menurut Cholissodin dan Riyandani (2016), antara lain sebagai berikut:

a) Swarm, merupakan jumlah partikel dalam suatu populasi. Ukuran swarm bergantung pada seberapa kompleks permasalahan yang akan diselesaikan. Secara umum, ukuran swarm pada algoritme PSO cenderung lebih kecil jika dibandingkan dengan algoritme evolusioner lainnya dalam melakukan pencarian solusi terbaik.

b) Partikel, merupakan suatu individu dalam suatu swarm yang merepresentasikan solusi untuk menyelesaikan permasalahan. Setiap partikel memiliki posisi dan kecepatan yang ditentukan oleh representasi solusi tersebut.

c) Personal best (pBest), merupakan posisi terbaik yang pernah dicapai oleh partikel dengan membandingkan nilai fitness pada posisi partikel saat ini dengan sebelumnya. Personal best dipersiapkan untuk mendapatkan solusi terbaik.

d) Global Best (gBest), merupakan posisi terbaik partikel yang diperoleh dengan membandingakan nilai fitness terbaik dari keseluruhan partikel dalam swarm.

e) Kecepatan (velocity), $v$ merupakan vektor yang menentukan arah perpindahan posisi partikel. Perubahan velocity dilakukan setiap iterasi dengan tujuan memperbaiki posisi partikel semula.

f) Bobot inersia (inertia weight), $w$ digunakan untuk mengontrol dampak dari perubahan velocity yang diberikan oleh partikel.

g) Koefisien akselerasi, merupakan faktor pengontrol sejauh mana partikel berpindah dalam satu iterasi. Secara umum nilai koefisien akselerasi $\mathrm{C} 1$ dan $\mathrm{C} 2$ adalah sama yaitu dalam rentang 0 sampai 4. Namun demikian, nilai tersebut dapat ditentukan sendiri untuk setiap penelitian berbeda.

Terdapat pseudo-code sebagai struktur umum algoritme PSO seperti ditunjukkan pada Gambar 3. Selanjutnya rumus yang digunakan pada algoritme PSO disajikan dalam Persamaan berikut

Rumus update kecepatan (velocity):

Persamaan 1

$v_{i, j}^{t+1}=w \cdot v_{i, j}^{t}+c_{1} \cdot r_{1}\left(\right.$ Pbest $\left._{i, j}^{t}-x_{i, j}^{t}\right)+c_{2} \cdot r_{2}\left(\right.$ Gbest $\left._{g, j}^{t}-x_{i, j}^{t}\right)$

Rumus update posisi:

Persamaan 2

$x_{i, j}^{t+1}=x_{i, j}^{t}+v_{i, j}^{t}$ 


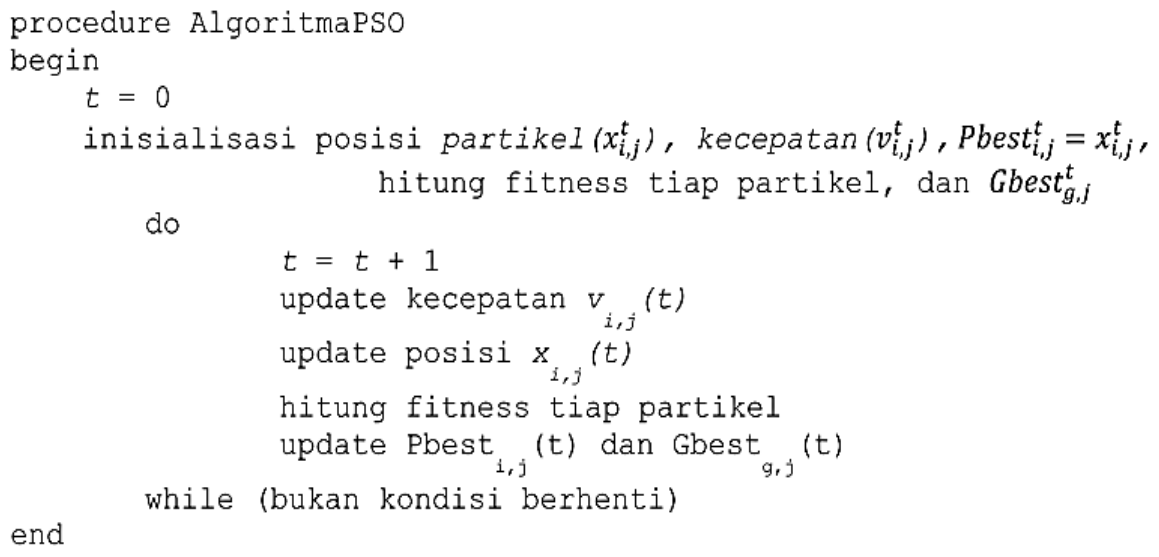

Gambar 3 Pseudocode Algoritme PSO

\section{Formulasi Permasalahan}

Permasalahan yang terdapat pada studi kasus penelitian ini seperti ditunjukkan Gambar 4, bahwa proses produksi industri tekstil tidak bertumpu pada satu daerah saja melainkan dibagi menjadi beberapa daerah produksi (region) atau selanjutnya akan disebut sebagai multi-site. Hal ini bertujuan untuk memaksimalkan sumber daya yang ada pada setiap daerah. Namun strategi ini juga menimbulkan permasalahan baru dalam hal perencaan proses produksi dikarenakan setiap daerah memiliki standar nilai upah yang beragam serta aturan yang berbeda pula. Untuk itu perencanaan produksi agregat multi-site diperlukan guna memaksilkan segala sumber daya sehingga didapatkan keuntungan yang optimal. Dalam hal ini meminimalkan biaya produksi merupakan tujuan utama.

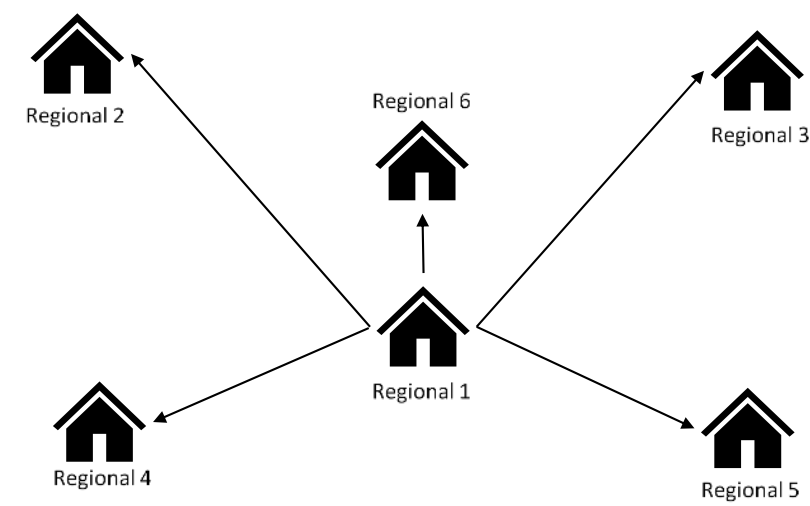

Gambar 4 Skema Produksi Multi-Site

\section{Results}

Dari penyelesain menggunakan metode PSO didapatkan hasil produksi untuk 6 region. Pada Tabel 1 ditunjukkan cost atau biaya produksi untuk masing-masing region.

Tabel 1 Biaya Produksi Masing-masing Region

\begin{tabular}{cc}
\hline Region ke- & Cost \\
\hline $\mathbf{1}$ & 369015000 \\
$\mathbf{2}$ & 428437000 \\
$\mathbf{3}$ & 430752000 \\
$\mathbf{4}$ & 480025000 \\
$\mathbf{5}$ & 513392000 \\
\hline
\end{tabular}




\begin{tabular}{ll}
\hline 6 & 513022500 \\
\hline
\end{tabular}

Selanjutnya Tabel 2 sampai dengan Tabel 7 merupakan rincian dari perencanaan produksi agregat untuk masing-masing region. Setiap periode perusahaan akan memperhitungkan biaya produksi regular time (rt), biaya produksi over time (ot), biaya produksi subcontract (st), biaya perekrutan pekerja (ht), biaya pemberhentian pekerja (ft) dan jumlah persediaan (it).

Tabel 2 Perencanaan Produksi Agregat Region 1

\begin{tabular}{cccccccccc}
\hline Periode & Permintaan & $\begin{array}{c}\text { Hari } \\
\text { Kerja }\end{array}$ & Produksi & rt & ot & st & ht & ft & it \\
\hline Agu-16 & 739 & 21 & 740 & 740 & 0 & 0 & 0 & 0 & 1 \\
Sep-16 & 313 & 20 & 674 & 674 & 0 & 0 & 0 & 0 & 362 \\
Okt-16 & 654 & 21 & 565 & 565 & 0 & 0 & 0 & 0 & 273 \\
Nov-16 & 902 & 21 & 1235 & 1092 & 143 & 0 & 0 & 0 & 606 \\
Des-16 & 475 & 21 & 1806 & 1092 & 336 & 378 & 0 & 0 & 1937 \\
Jan-17 & 711 & 20 & 780 & 780 & 0 & 0 & 0 & 0 & 2006 \\
Feb-17 & 777 & 22 & 1579 & 1144 & 352 & 83 & 0 & 0 & 2808 \\
Mar-17 & 1314 & 20 & 1302 & 1040 & 262 & 0 & 0 & 0 & 2796 \\
Apr-17 & 997 & 20 & 1536 & 1040 & 320 & 176 & 0 & 0 & 3335 \\
Mei-17 & 1269 & 17 & 1577 & 884 & 272 & 421 & 0 & 0 & 3643 \\
Jun-17 & 3396 & 21 & 1958 & 1092 & 336 & 530 & 0 & 0 & 2205 \\
Jul-17 & 4017 & 22 & 1791 & 1144 & 352 & 295 & 0 & 0 & -21 \\
\hline
\end{tabular}

Tabel 3 Perencanaan Produksi Agregat Region 2

\begin{tabular}{cccccccccc}
\hline Periode & Permintaan & $\begin{array}{c}\text { Hari } \\
\text { Kerja }\end{array}$ & Produksi & rt & ot & st & ht & ft & it \\
\hline Agu-16 & 1439 & 21 & 1443 & 1443 & 0 & 0 & 0 & 0 & 4 \\
Sep-16 & 838 & 20 & 1358 & 1358 & 0 & 0 & 0 & 0 & 524 \\
Okt-16 & 871 & 21 & 882 & 882 & 0 & 0 & 0 & 0 & 535 \\
Nov-16 & 947 & 21 & 608 & 608 & 0 & 0 & 0 & 1 & 196 \\
Des-16 & 671 & 21 & 1509 & 1509 & 0 & 0 & 0 & 0 & 1034 \\
Jan-17 & 911 & 20 & 2243 & 1440 & 360 & 443 & 0 & 0 & 2366 \\
Feb-17 & 562 & 22 & 2717 & 1584 & 396 & 737 & 0 & 0 & 4521 \\
Mar-17 & 952 & 20 & 2491 & 1440 & 360 & 691 & 0 & 0 & 6060 \\
Apr-17 & 1491 & 20 & 1406 & 1406 & 0 & 0 & 0 & 0 & 5975 \\
Mei-17 & 2660 & 17 & 1408 & 1224 & 184 & 0 & 0 & 0 & 4723 \\
Jun-17 & 2660 & 21 & 2439 & 1512 & 378 & 549 & 0 & 0 & 4502 \\
Jul-17 & 6658 & 22 & 2158 & 1144 & 352 & 295 & 0 & 0 & -21 \\
\hline
\end{tabular}


Tabel 4 Perencanaan Produksi Agregat Region 3

\begin{tabular}{cccccccccc}
\hline Periode & Permintaan & $\begin{array}{c}\text { Hari } \\
\text { Kerja }\end{array}$ & Produksi & rt & ot & st & ht & ft & it \\
\hline Agu-16 & 2766 & 21 & 3419 & 1365 & 420 & 546 & 5 & 0 & 653 \\
Sep-16 & 1186 & 20 & 736 & 736 & 0 & 0 & 0 & 0 & 203 \\
Okt-16 & 864 & 21 & 1231 & 1231 & 0 & 0 & 0 & 0 & 570 \\
Nov-16 & 944 & 21 & 598 & 598 & 0 & 0 & 0 & 1 & 224 \\
Des-16 & 687 & 21 & 624 & 624 & 0 & 0 & 0 & 0 & 161 \\
Jan-17 & 790 & 20 & 991 & 991 & 0 & 0 & 0 & 0 & 362 \\
Feb-17 & 805 & 22 & 1794 & 1430 & 364 & 0 & 0 & 0 & 1351 \\
Mar-17 & 615 & 20 & 1955 & 1300 & 400 & 255 & 0 & 0 & 2691 \\
Apr-17 & 1676 & 20 & 1809 & 1300 & 400 & 109 & 0 & 0 & 2824 \\
Mei-17 & 2118 & 17 & 1854 & 1105 & 340 & 409 & 0 & 0 & 2560 \\
Jun-17 & 2617 & 21 & 3026 & 1365 & 420 & 546 & 4 & 0 & 2969 \\
Jul-17 & 5727 & 22 & 2722 & 1430 & 440 & 572 & 2 & 0 & -36 \\
\hline
\end{tabular}

Tabel 5 Perencanaan Produksi Agregat Region 4

\begin{tabular}{cccccccccc}
\hline Periode & Permintaan & $\begin{array}{c}\text { Hari } \\
\text { Kerja }\end{array}$ & Produksi & rt & ot & st & ht & ft & it \\
\hline Agu-16 & 1808 & 21 & 2890 & 2016 & 504 & 370 & 0 & 0 & 1082 \\
Sep-16 & 1221 & 20 & 1252 & 1252 & 0 & 0 & 0 & 0 & 1113 \\
Okt-16 & 1455 & 21 & 1582 & 1582 & 0 & 0 & 0 & 0 & 1240 \\
Nov-16 & 1312 & 21 & 861 & 861 & 0 & 0 & 0 & 1 & 789 \\
Des-16 & 1129 & 21 & 902 & 902 & 0 & 0 & 0 & 0 & 562 \\
Jan-17 & 1397 & 20 & 862 & 862 & 0 & 0 & 0 & 1 & 27 \\
Feb-17 & 594 & 22 & 3419 & 2112 & 528 & 779 & 0 & 0 & 2852 \\
Mar-17 & 1003 & 20 & 1833 & 1833 & 0 & 0 & 0 & 0 & 3682 \\
Apr-17 & 2006 & 20 & 2951 & 1920 & 480 & 551 & 0 & 0 & 4627 \\
Mei-17 & 3429 & 17 & 2635 & 1632 & 408 & 595 & 0 & 0 & 3833 \\
Jun-17 & 3579 & 21 & 3458 & 2016 & 504 & 938 & 0 & 0 & 3712 \\
Jul-17 & 7069 & 22 & 3370 & 2112 & 528 & 730 & 0 & 0 & 13 \\
\hline
\end{tabular}


Tabel 6 Perencanaan Produksi Agregat Region 5

\begin{tabular}{cccccccccc}
\hline Periode & Permintaan & $\begin{array}{c}\text { Hari } \\
\text { Kerja }\end{array}$ & Produksi & rt & ot & st & ht & ft & it \\
\hline Agu-16 & 1843 & 21 & 2814 & 1911 & 588 & 315 & 0 & 0 & 971 \\
Sep-16 & 866 & 20 & 627 & 627 & 0 & 0 & 0 & 2 & 732 \\
Okt-16 & 1202 & 21 & 728 & 728 & 0 & 0 & 0 & 0 & 258 \\
Nov-16 & 1327 & 21 & 1262 & 1262 & 0 & 0 & 0 & 0 & 193 \\
Des-16 & 744 & 21 & 1833 & 1833 & 0 & 0 & 0 & 0 & 1282 \\
Jan-17 & 1304 & 20 & 829 & 829 & 0 & 0 & 0 & 0 & 807 \\
Feb-17 & 1393 & 22 & 2893 & 2002 & 616 & 275 & 0 & 0 & 2307 \\
Mar-17 & 1650 & 20 & 2579 & 1820 & 560 & 199 & 0 & 0 & 3236 \\
Apr-17 & 1606 & 20 & 2534 & 1820 & 560 & 154 & 0 & 0 & 4164 \\
Mei-17 & 2367 & 17 & 2440 & 1547 & 476 & 417 & 0 & 0 & 4237 \\
Jun-17 & 4374 & 21 & 3316 & 1911 & 588 & 817 & 0 & 0 & 3179 \\
Jul-17 & 6339 & 22 & 3156 & 2002 & 616 & 538 & 0 & 0 & -4 \\
\hline
\end{tabular}

Tabel 7 Perencanaan Produksi Agregat Region 6

\begin{tabular}{cccccccccc}
\hline Periode & Permintaan & $\begin{array}{c}\text { Hari } \\
\text { Kerja }\end{array}$ & Produksi & rt & ot & st & ht & ft & it \\
\hline Agu-16 & 4047 & 21 & 4270 & 1512 & 378 & 756 & 8 & 0 & 223 \\
Sep-16 & 1582 & 20 & 1505 & 1440 & 65 & 0 & 0 & 0 & 146 \\
Okt-16 & 932 & 21 & 841 & 841 & 0 & 0 & 0 & 0 & 55 \\
Nov-16 & 714 & 21 & 2012 & 1512 & 378 & 122 & 0 & 0 & 1353 \\
Des-16 & 983 & 21 & 625 & 625 & 0 & 0 & 0 & 0 & 995 \\
Jan-17 & 781 & 20 & 1402 & 1402 & 0 & 0 & 0 & 0 & 1616 \\
Feb-17 & 879 & 22 & 1932 & 1584 & 348 & 0 & 0 & 0 & 2669 \\
Mar-17 & 628 & 20 & 2309 & 1440 & 360 & 509 & 0 & 0 & 4350 \\
Apr-17 & 1808 & 20 & 2508 & 1440 & 360 & 708 & 0 & 0 & 5050 \\
Mei-17 & 2344 & 17 & 733 & 733 & 0 & 0 & 0 & 0 & 3439 \\
Jun-17 & 2918 & 21 & 2598 & 1512 & 378 & 708 & 0 & 0 & 3119 \\
Jul-17 & 5305 & 22 & 2142 & 1584 & 396 & 162 & 0 & 0 & -44 \\
\hline
\end{tabular}

Dari hasil yang telah diperoleh dengan menggunakan metode PSO dapat disimpulkan bahwa biaya produksi perusahaan untuk 6 region adalah sebesar Rp2.734.643.500,-. Dengan rincian perencanaan agregat yang juga telah dihasilkan dapat menjadi acuan perusahaan dalam menentukan strategi selama 12 bulan ke depan. 


\section{Kesimpulan}

Berdasarkan penelitian yang telah dilakukan terkait solusi atas permasalahan perencanaan produksi agregat multi-site, maka didapatkan kesimpulan sebagai berikut:

1. Representasi solusi dengan menggunakan integer dapat mewakili nilai solusi (jumlah produksi) pada perencanaan agregat produksi. Pada tahap awal, representasi tersebut masuk ke dalam proses PSO dimana setiap satu baris representasi solusi menjadi satu partikel.

2. Mekanisme yang dilakukan oleh penulis terkait algoritme PSO dikatakan berhasil. PSO dapat menentukan nilai produksi yang tepat untuk masing-masing region selama 12 periode .

3. Metode usulan penulis yakni algoritme PSO dapat dikatakan berhasil dalam mencari solusi optimal untuk permasalahan perencanaan produksi agregat. Hal ini terbukti dari hasil algoritme PSO berupa biaya produksi sebesar Rp2.734.643.500,- lebih rendah dibandingkan dengan metode konvensional yang selama ini digunakan yakni sebesar Rp2.817.900.000,-. Disamping itu penelitian ini juga menghasilkan detail perencanaan agregat untuk 6 region yang dapat dipakai sebagai acuan pengambilan keputusan perusahaan di masa mendatang.

\section{Referensi}

1. O. Saracoglu, M. C. Arslan, and M. Turkay, "Aggregate Planning Problem from Sustainability Perspective," Int. Conf. Adv. Logist. Transp. Aggreg., pp. 181-186, 2015.

2. L. Nafisah, Sutrisno, and Y. E. H. Hutagaol, "Perencanaan Produksi Menggunakan Goal Programming (Studi Kasus di Bakpia Pathuk 75 Yogyakarta)," Spektrum Ind., vol. 14, pp. 109-230, 2016.

3. I. A. Octavianti, N. W. Setyanto, C. Farela, and M. Tantrika, "Perencanaan Produksi Agregat Produk Tembakau Rajang P01 Dan P02 Di PT X," J. Rekayasa dan Manaj. Sist. Ind., vol. 1, no. 2, pp. 264-274, 2012.

4. W. F. Mahmudy, "Improved Particle Swarm Optimization untuk Menyelesaikan Permasalahan Part Type Selection dan Machine Loading pada Flexible Manufacturing System (FMS)," Konf. Nas. Sist. Inf. , Univ. Klabat, Airmadidi, Minahasa Utara, Sulawesi Utara, no. August, pp. 1003-1008, 2015.

5. W. F. Mahmudy, "Optimization of Part Type Selection and Machine Loading Problems in Flexible Manufacturing System Using Variable Neighborhood Search," IAENG Int. J. Comput. Sci., vol. 42:3, no. July, pp. 254-264, 2015.

6. I. Cholissodin and E. Riyandani, SWARM INTELLIGENCE (Teori \& Case Study). Malang: Fakultas Ilmu Komputer, Universitas Brawijaya, 2016.

(C) 2019 by the authors. Submitted for possible open access publication under the terms and conditions of the Creative Commons Attribution (CC BY) license (http://creativecommons.org/licenses/by/4.0/). 